\title{
United States and Canada Sign Agreement on Ocean Drilling Programme
}

The National Science Foundation (NSF) and the Canadian Department of Energy, Mines and Resources today (April 15) signed a Memorandum of Understanding for Cooperation in the Ocean Drilling Program (ODP), an international project to explore the ocean basins to find clues on how the Earth was formed and developed. The agreement calls for Canadian participation, in principle, for the nine-years' duration of the ODP.

ODP scientists use the 470-foot ( $c$ 143-m), Nova Scotia-built, drillship JOIDES Resolution to study sediments and rocks that underlie the ocean basins, in order to gain more information on the structure of the planet, the structure of the Earth's interior, life in the oceans, and changes in global climate.
Under terms of the memorandum, Canada will contribute US $\$ 2.5$ millions annually to the project. This entitles Canadian research workers to have two scientific representatives on each cruise, and one co-chief scientist a year. Canadians will also take part in ODP planning, including the selection of drill-sites. In September and October of 1985, JOIDES Resolution will drill in the Labrador Sea and Baffin Bay. Co-chief scientists from the Bedford Institute, Dartmouth, Nova Scotia, and the University of Rhode Island, will lead the expedition.

RALPH KAZARIAN
National Science Foundation
I800 G Street
Washington
DC 20550, USA.

\section{Pollution Threatening Swiss and German Forests}

The battle to save Switzerland's forests from the effects of air pollution is now officially engaged. On one side is an influential automobile lobby opposed to lower speed-limits as a means of saving trees. On the other side are environment-conscious politicians and an array of conservationist interest-groups. And this is no local issue: neighbouring West Germany is already on the horns of much the same dilemma, and Switzerland's case could soon be repeated practically throughout Europe.

The crisis may have come to a head soonest in Switzerland because forest loss is a matter of life and death in some parts of such a mountainous country. Ironically, no nation has done more than Switzerland to make forest conservation a way of life, particularly in the interests of landslide and avalanche control. More than 100 years ago, Switzerland passed a tough, comprehensive law to make sure that its forests would be preserved into posterity. The 1876 measure of some Cantons, designed to halt overexploitation of forests, was extended nationwide in 1902. It required that all tree-cutting be followed by generous replanting. But now the nation is in the grips of a Manmade crisis that is threatening to undo over a century of disciplined good work.

Most existing studies of 'acid rain' pollution have blamed fallout from power-stations and factories as the main culprit. The Swiss national network of air-pollution monitoring stations (NABEL), however, published a bombshell report in 1983 which showed that Switzerland's share of the problem could not be blamed wholly on heavy industry at home or in neighbouring countries.

NABEL had figures to show, that oxides of nitrogen, $80 \%$ of them produced by motor-vehicle exhausts, were building up in the environment at a rate exceeding $10 \%$ a year. NABEL also said that oxides of sulphur from othermainly industrial-sources inside and outside Switzerland were building up at a similar rate. Both categories of oxides are known triggers of the 'acid rain' phenomenon, though the relative importance of the two varies considerably from country to country or from region to region.

Reinforcing the NABEL report, field studies produced a mass of evidence to show that, across the whole Swiss landscape of alps and river valleys, an average of one in three trees is 'doomed or dead'. In some areas, such as the heavily-populated northern region around Switzerland's largest city, Zurich, and in the southern alpine Cantons of the Grisons and Valais, the toll is nearer one in two.

\section{Limits}

Last year, in a move to counter the car-exhaust pollution threat, the Federal Government imposed speed-limits of
$120 \mathrm{kph}$ on autoroutes and $80 \mathrm{kph}$ on minor roads.* It is now considering cutting the top speed on autoroutes to $100 \mathrm{kph}$. In 1986 motorists will face mandatory requirements to use exhaust catalysers and lead-free gasoline.

But the automobile lobby in Switzerland has recently succeeded in forcing a national referendum calling for the repeal of the speed-limits imposed last year! An inconclusive stand-off between 'Green' and 'Machine' is threatened in what is arguably Europe's most environment-conscious nation.

Yet Switzerland is not alone. In the Federal Republic of Germany, a quarter of which is still forest-covered, a recent study showed that as many as half of the nation's trees may have been damaged already by pollution. The Government is caught between pressure for lower speed-limits and other stricter controls from the Greens Party, and the reluctance of its Common Market partners to adopt such standards. $\dagger$

\section{'Five Minutes to Midnight'}

Waldsterben, or death of the forests, is part of a growing problem in central Europe, Scandinavia, and North America. Events in Switzerland could be a significant test-case for state intervention to solve the frightening environmental problems that arise from acidic fallout wherever it occurs.

'It is five minutes to midnight', says Professor Pierre Goeldlin, Director of Lausanne's Zoological Museum and a Regional Councillor of IUCN. Goeldlin and like-minded conservationists have recently gained a wide audience in Switzerland, as public concern for the problem grows. Public concern, however, doesn't always translate immediately into swift action, and Goeldlin and others are concerned that measures to stop the killing of the trees aren't being taken quickly enough.

'I hope that the debate and the measures being proposed will induce our neighbours to move as far in the same

\footnotetext{
* We heard of these limits and at first tried to keep to them but, being chronically passed by a large proportion of cars and even heavier vehicles travelling in the same direction - often with impatient hoots from them to move on-did not long persist. - Ed.

${ }^{\dagger}$ Latterly (June to September 1985) we have been appalled by the death or unhealthy appearance (especially die-back) of a shockingly large proportion of trees and shrubs not only around us in Switzerland but also very widely along the road and on the horizon when driving slowly from Oxford to Cambridge in England and subsequently in the Banff National Park and Kananaskis Provincial Park in Alberta, Canada.-Ed.
} 
direction or even further,' he says, 'Because if we don't react very rapidly, we may see it becoming an irreversible problem.'

\section{Forests No Luxury}

Professor Goeldlin makes it clear that forests are no luxury for Switzerland: 'The death of the forests in Switzerland is certainly a problem endangering the security of our country, he says. His remarks were echoed by Dr Claude Martin, of WWF-Suisse, an IUCN member who said: 'It is a very sad, ironic situation, Switzerland did everything to protect its forests, and yet it has still gotten into this mess.'

There are certainly important amounts of acidifying pollution in Switzerland which cannot be blamed on car exhausts, and which come from sources which the Swiss nation cannot control. The country's own industries emit the lowest level of sulphur pollution in Europe. But a lot of this form of fallout is imported on the wind, especially from Germany.

Switzerland, however, has the densest road network in Europe, with 63,000 kilometres of paved roads, and an extremely high density of automobiles -2.7 millions for its 5.5 millions of people. It is hardly surprising, therefore, that so much of Switzerland's surplus of airborne oxides turns out to be home-made.

\section{Killer Ozone}

'In mountain areas another problem is that [effluent substances are] converted partly by radiation from the sun at higher levels into very aggressive plant-toxic substances, such as ozone and other so-called "fog toxins", says Dr Martin. Yet 'It is very difficult to analyse exactly what pollution comes from inside or outside the country,' says Professor Goeldlin. 'And I don't think it makes any great sense to entertain this approach, because the most important thing is that transboundary pollution can go back and forth. It can go to Germany and be [wafted] back to Switzerland. That is why the problem must be dealt with on an international level,' he added.

Although there has been much hue and cry about Waldsterben throughout Europe, actual moves to counter the problem have been slowed down in Switzerland and elsewhere by a lack of agreement on ways and means. Switzerland, not being a member of the European Community, so far has 'gone it alone' on lowering speed-limits to save trees. Public pressure evidently inspired a majority of the Swiss Lower House to call for a more drastic reduction in speed limits than the 10 kilometres lopped off the $130 \mathrm{kph}$ motorway limit by the ruling seven-member Federal Council last year.

At the same time, however, the Upper House has sidestepped the issue of lowering limits further by refusing to endorse the Lower House call, and referring the matter back to the Federal Council. Meanwhile, a group backed by car clubs and industry lobbyists has formed a new "Automobile Party' with the limited platform of easing rather than tightening speed restrictions, and creating more parking space!

\section{Petition}

The opposition has mustered some 263,000 names163,000 more than needed - on a petition that will force a national anti-speed-limit referendum. This is despite the fact that the Swiss Government has provided conclusive evidence linking the death of trees to exhaust emissions. 'One never knew before what the effects of the exhaust gases were, as never before-not in Europe, at least-have methodical studies been done on the total emissions and their possible effects,' Dr Martin said. Now 'it has been proven in Germany and Switzerland that the nitric oxide in exhaust emissions increase at higher speeds, kilometre by kilometre, and not just by time. So if you have more cars driving more speedily, you have a relevant increase in the nitric oxide in exhausts.'

The Swiss also intend to impose the use of catalysers and lead-free gasoline. But Professor Goeldlin urges that the Government should take more preventive measures, such as removing dead trees and liming the ground, to counter further acidification. The Swiss Government, however, seems to be bent on controlling causes rather than effects, with decisions pending on limiting the emissions of diesel motors (primarily in trucks), mandating US emission standards, reducing the sulphur content of oil, and lowering the price of lead-free fuel to make it competitive with leaded 'super' and 'regular'.

Whatever measures are imposed, Switzerland and West Germany may end up taking action alone-especially as political pressure from the Greens in Germany and the Socialists in Switzerland is building up considerably on this issue.

\section{The Last Walds?}

In West Germany, the Ministry of Food, Agriculture and Forestry reports that $50.2 \%$ of the country's timber stock is suffering from 'pollution-related' diseases, though not necessarily all as a consequence of acidification. Yet people still drive at breakneck speeds along the Autobahns. At the same time, while politicians and car and industry lobbyists fight out the question of imposing speed-limits, the Government has not yet made up its mind on the issue. Instead, its Transport and Interior Ministries (which carry environment portfolios) are undertaking a joint study of Autobahns in the north, to see if lowering the speed-limit to $100 \mathrm{kph}$ would be effective in reducing damage to trees. Also, the Government has offered incentives to motorists, such as a reduction in the road-tax for those who equip their cars with catalytic converters, or cheaper prices for lead-free gasoline. But the use of catalytic converters will not become compulsory until 1989.

Meanwhile, West Germany is meeting resistance from its European Community partners who argue that catalytic converters may not be the best or cheapest way to deal with pollution. The partners say that fitting converters on the smaller French and Italian cars is too expensive, and a disadvantage to sales. However, a March meeting of European Community environment ministers reached some compromises on the phased introduction of low-pollution cars. They agreed that big cars must have pollution controls by 1989 , medium cars by 1993 , and small cars by 1994 , while lead-free gasoline must be available throughout the Community by 1989 . They also agreed to limited tax incentives to encourage motorists to buy 'environment-friendly' cars. The compromises will allow the West Germans to go ahead with certain pollution-reducing measures, but they will have to delay some others from 1986 to 1989.

At the same time, the argument has been 'turned on its head' in Britain, where Switzerland's findings on car exhaust emissions have been used to deflect criticism of British inaction over pollution from coal-burning powerstations. Energy mandarins claim that there is too little evidence to brand British power-stations as a principal source of acid rain in downwind Scandinavia, implying that further research on the spot might show that much of the pollution in Scandinavia is home-made. 


\section{Quibbling}

Conservationists throughout Europe see this kind of quibbling as symptomatic of a deep-rooted and stubborn refusal to face up to the problem of dying forests, despite the majority concern that has been voiced in opinion polls in many countries-including conservation-conscious Switzerland.

'There is still a part of the population that refuses to accept the reality, now proven at the European level,' says Professor Goeldlin. 'They refuse to accept it for several reasons, including its complexity and the fact [that] there has been lack of really good information. But the problem is much broader than simply the death of the forests.'

Professor Goeldlin points out that sulphur and nitric oxide emissions have also caused serious problems for agriculture, underground water, and monuments and buildings in cities, as well as posing a threat to human health. 'We seem to forget that using the air as a vehicle for pollutants-using it for the disposal of wastes-doesn't cost anything. But it costs a lot to try to repair all the damage,' he says. 'This is what happened to our waters, and we needed 50 million francs to clean them up. Lake Geneva (Lac Léman) is still on the brink of ruin.'

\section{Lessons}

All is not lost yet, however, according to both Goeldlin and Martin. They believe valuable lessons will be learned from the Swiss experience. But they both hope other nations will attack the problem quickly, because Switzer- land cannot continue to tackle it alone. "The most important thing for a lot of European countries is to acknowledge that automobile exhausts are a very relevant source,' Dr Martin says. 'The fact that nitric oxides (from automobile exhausts) aren't being discussed extensively in some countries, is due to their higher rate of sulphur dioxide emissions. So I think: if we want European countries to look at our example, they should look at the effects of nitric oxide.'

Professor Goeldlin adds: 'Other countries should learn that [our] country is [currently] taking unilateral measures, even though we know perfectly well that a very important part of the acidification is being imported into Switzerland. So this should be... a stimulating model, putting pressure on other governments to feel solidarity with us.'

Both men believe that continued public pressure and information on the problem will push governments into action. They also believe that the Swiss experience will amplify international concern for the environment. 'We have to call the situation very, very bad,' says Dr Martin. 'But if I look globally at the whole situation, maybe the Waldsterben helps us in the sense that people will start getting more conscious of the environment,' adding: 'maybe we will have, in the next 20 or 30 years, air that is better than we have now.'

THOMAS W. NETTER
IUCN Press Service
World Conservation Centre
Avenue du Mont-Blanc
1196 Gland, Switzerland.

THOMAS W. NETTER CN Press Service 1196 Gland, Switzerland.

\section{Conservation of Virgin Forests and Woodpeckers in Sweden}

We are delighted to note, from the Council of Europe's ever-informative Newsletter-Nature (No. 85/4), that Sweden is taking a lead in the following two items that should interconnect vividly in Nature-loving environmentalists' minds:

Protection will be afforded to three large tracts of virgin mountain forest in the Storuman area of northern-central Sweden. This decision by the Government puts an end to a two-years-old conflict between the Swedish National Environment Protection Board and the Directorate of Crown Forests. The latter administers $85 \%$ of the country's 'prealpine' forest, which remains unexploited and is particularly precious to the cause of virgin forest conservation in Sweden. Out of a total of 670,000 hectares of listed virgin forest, the 248,000 hectares concerned are particularly valuable. The National Swedish Environment Protection Board has also had its budget for the purchase of protected areas increased from 20 to 40 million $\mathrm{kr}$.

The Middle-spotted Woodpecker (Dendrocopos medius) has been extinct in Sweden-since 1982, its disappearance being linked to that of wooded pastureland, and hence its favourite tree, the oak (Quercus sp.). Now there are fears that the White-backed Woodpecker (Dendrocopos leucotos) will meet the same fate. Its population fell by half between 1970 and 1982, from $c a 100$ to 50 pairs, and this has occurred in areas where the population has always been relatively large. The cause is attributable to a forestry policy which favours the disappearance of non-profitable deciduous forest. The implementation of the new broadleaf woodland legislation (Newsletter 85/1) will enable this process to be reversed, and may save the White-backed Woodpecker and other species which are dependent on this kind of habitat.

The Swedish Association for the Protection of Nature, in collaboration with the Swedish National Environment Protection Board, the Directorate of Crown Forests, and a number of private landowners, intends to list and mark 250,000 old hollow trees, in order that they may be protected as an essential habitat for certain kinds of birds.

\section{People's Environmental Action for Doon Valley, India}

On 12 March 1985, just 100 days after the environmental disaster of Bhopal, an Indian Supreme Court bench headed by Justice P.N. Bhagawati gave a pioneering judgement on India's first major environmental litigation, upholding the need for conservation in the broader social interest. The public-interest litigation was filed by the citizens of Doon Valley as a part of their struggle to save this unique and fragile ecobiome of the Himalayas.* The groups involved

* See these same Authors' illustrated account of 'The Conflict over Limestone Quarrying in Doon Valley, Dehradun, India', published on pp. 131-9 of our latest issue.-Ed. in this litigation were the Rural Litigation and Entitlement Centre, The Friends of the Doon, Save Mussoorie Society, and the City Board of Mussoorie.

The Doon Valley is a distinct ecobiome in the foothills of the Himalayas. It also forms the administrative unit of Tehsil Dehradun in the State of Uttar Pradesh in India. The Valley is endowed with rich and perennial water resources that supported flourishing forests, agriculture, horticulture, and the growth of an urban settlement based on research and educational institutions. The Valley also has a rich limestone deposit in its ecologically sensitive northern part. Recently, serious conflict of interest had developed 